\title{
Cerebral venous sinus thrombosis associated with thrombocytopenia post-vaccination for COVID-19
}

\author{
Gian Paolo Castelli ${ }^{*}$ (D), Claudio Pognani ${ }^{1}$, Carlo Sozzi ${ }^{2}$, Massimo Franchini ${ }^{3}$ and Luigi Vivona ${ }^{4}$
}

\section{Introduction}

Cerebral venous sinus thrombosis (CVST) is a rare form of stroke generally occurring in younger patients (typically $<50$ years old), predominantly women and amounting to $0.5-1 \%$ of all strokes. Incidence is about $5-16$ cases per 1 million people per year [1-3].

CVST has been reported in COVID-19 patients associated with thrombocytopenia [4, 5]; on March 15, 2021, the Paul Ehrlich Institut (Federal Institute for vaccines and biomedicines) reported CVST in seven patients 20-50 years old after vaccination with COVID-19 vaccine AstraZeneca.

We report about a previously healthy 50 -year-old Caucasian man admitted to the city hospital of Mantua on March 15, 2021, with severe headache during the previous four days, slight deviation of the right buccal rim, loss of strength in the right lower limb, unstable walking and slight visual impairment. On March 4, 2021, he had received the first dose of the anti-COVID-19 AstraZeneca vaccine with no immediate adverse reaction.

On examination, he was apyretic, arterial pressure $150 / 80 \mathrm{mmHg}$ and heart rate $80 / \mathrm{min}, \mathrm{SpO}_{2} 99 \%$ in room air, GCS 15, pain numerical rating scale 8/10. Laboratory blood tests showed marked abnormalities in blood coagulation (Table 1). The patient was a volunteer blood donor, and previous routine blood tests had repeatedly reported normal platelet counts. SARS-CoV-2 Buffer

*Correspondence: gianpaolo.castelli@gmail.com

1 Department of Anesthesiology and Intensive Care, "Carlo Poma" Hospital, ASST Mantova, Via Lago Paiolo, 10, 46100 Mantova, Italy Full list of author information is available at the end of the article
(RT-PCR) and Anti-SARS-CoV-2 Antibody Search were negative. A brain $\mathrm{CT}$ scan showed intra-parenchymal haemorrhage in the left hemisphere, while CT angiography showed multiple bleeding spots within the parenchymal haemorrhage and lack of opacification of the left transverse and sigmoid sinuses, suggesting thrombosis of the venous sinuses (Fig. 1). Four hours after admission, the patient had deteriorated to GCS 8 , right hemiplegia, localization of the painful stimulus to the left, no execution of orders nor verbal production. He showed isochoric, isocyclic pupils and vomiting. The patient was transferred to the intensive care unit (ICU), and a thromboelastogram (TEG6S, Haemonetics) showed a prolonged reaction time, a decreased platelet function and lack of fibrinogen, with marked reduction of maximum amplitude of the clot; fibrinogen concentrate (10 g total) and platelet (4 units total) were administered.

Six hours after ICU admission, the patient had become medium mydriatic: he was intubated, sedated and paralysed and underwent a second CT scan, which documented the increase in the haemorrhagic focus, the initial transtentorial herniation of the left temporal uncus and a shift of the midline to the right. The patient underwent a bilateral decompressive craniectomy, which confirmed diffuse thrombosis of the cortical veins. Upon returning from the operating room, a subsequent TEG6S showed normalization of the clot formation rate and reduced clot strength, with PLT had fall back to $15,000 / \mathrm{mcL}$.

Antiplatelet antibodies were negative, while a heterozygous state for the MTHFR thrombophilic mutation with increased levels of hyperhomocysteine and concomitant folate deficiency were reported post-mortem.

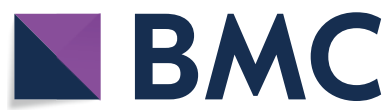

(c) The Author(s) 2021. Open Access This article is licensed under a Creative Commons Attribution 4.0 International License, which permits use, sharing, adaptation, distribution and reproduction in any medium or format, as long as you give appropriate credit to the original author(s) and the source, provide a link to the Creative Commons licence, and indicate if changes were made. The images or other third party material in this article are included in the article's Creative Commons licence, unless indicated otherwise in a credit line to the material. If material is not included in the article's Creative Commons licence and your intended use is not permitted by statutory regulation or exceeds the permitted use, you will need to obtain permission directly from the copyright holder. To view a copy of this licence, visit http://creativecommons.org/licenses/by/4.0/. The Creative Commons Public Domain Dedication waiver (http://creativeco mmons.org/publicdomain/zero/1.0/) applies to the data made available in this article, unless otherwise stated in a credit line to the data. 
Table 1 Abnormal laboratory parameters

\begin{tabular}{lll}
\hline Parameter & Patient's values & Normal values \\
\hline Platelets $\left(10^{9} / \mathrm{L}\right)$ & 20 & $150-400$ \\
Fibrinogen $(\mathrm{mg} / \mathrm{dL})$ & 98 & $150-450$ \\
D-dimer $(\mathrm{ng} / \mathrm{mL})$ & $>10,000$ & $<500$ \\
C reactive protein $(\mathrm{mg} / \mathrm{L})$ & 17.6 & $<5$ \\
Coagulation factor XIII (\%) & 35 & $70-150$ \\
Methylenetetrahydrofolate reduc- & Heterozygous & Absent \\
tase $($ MTHFR) mutation $(\mathrm{C677T})$ & & $<12$ \\
Homocysteine $(\mu \mathrm{mol} / \mathrm{L})$ & 16.7 & $3.9-26.8$ \\
Folic acid $(\mathrm{ng} / \mathrm{mL})$ & 0.9 & \\
\hline
\end{tabular}

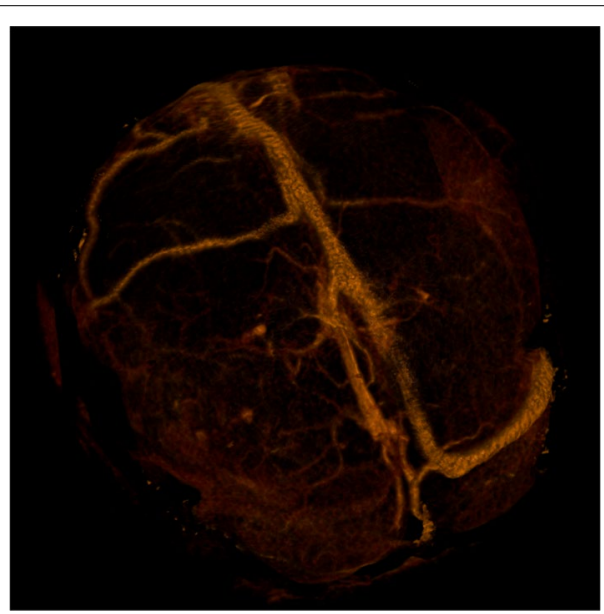

Fig.13D reconstruction with lack of opacification of the left transverse sinus

Haemodynamic instability, mydriasis and lack of intracerebral blood flow at CT angiography led to the diagnosis of brain death, approximately $48 \mathrm{~h}$ after admission to the hospital.

\section{Discussion}

SARS-CoV-2 infection has been associated with hypercoagulability, with a high incidence of venous thromboembolism including pulmonary embolism and deep vein thrombosis. Physicians should also be alert for signs and symptoms related to thromboembolism when they occur in patients who have recently been vaccinated with the COVID-19 AstraZeneca vaccine.

\section{Acknowledgements}

Not applicable.

\section{Authors' contributions}

GPC, CP, CS and MF conceived and designed the study; GPC, CS and MF contributed in data management; GPC, CP, CS and MF collected and analysed the data; GPC, MF and LV contributed in data analysis, interpretation of the data and drafting the manuscript. All authors read and approved the final manuscript.

\section{Funding}

No funds have been received and will be received for this study.

\section{Availability of data and materials}

The dataset used and/or analysed during the current study is available from the corresponding author on reasonable request.

\section{Declarations}

\section{Ethics approval and consent to participate}

The need for informed consent from individual patients was waived owing to the retrospective and observational nature of the study.

\section{Consent for publication}

Not applicable.

\section{Competing interests}

The authors declare that they have no competing interests.

\section{Author details}

${ }^{1}$ Department of Anesthesiology and Intensive Care, "Carlo Poma" Hospital, ASST Mantova, Via Lago Paiolo, 10, 46100 Mantova, Italy. ${ }^{2}$ Neuroradiology, "Carlo Poma" Hospital, ASST Mantova, Mantova, Italy. ${ }^{3}$ Department of Hematology and Transfusion Medicine, "Carlo Poma" Hospital, ASST Mantova, Mantova, Italy. ${ }^{4}$ Department of Pathophysiology and Transplantation, University of Milan, Milan, Italy.

Received: 6 April 2021 Accepted: 8 April 2021

Published online: 12 April 2021

\section{References}

1. Saposnik G, Barinagarrementeria F, Brown RD Jr, American Heart Association Stroke Council and the Council on Epidemiology and Prevention, et al. Diagnosis and management of cerebral venous thrombosis: a statement for healthcare professionals from the American Heart Association/ American Stroke Association. Stroke. 2011;42(4):1158-92. https://doi.org/ 10.1161/STR.0b013e31820a8364.

2. Ferro JM, Bousser MG, Canhão P, et al. European Stroke Organization guideline for the diagnosis and treatment of cerebral venous thrombosis - endorsed by the European Academy of Neurology. Eur Stroke J. 2017;2(3):195-221.

3. Silvis SM, de Sousa DA, Ferro JM, Coutinho JM. Cerebral venous thrombosis. Nat Rev Neurol. 2017;13(9):555-65.

4. Cavalcanti DD, Raz E, Shapiro M, Dehkharghani S, Yaghi S, Lillemoe K, Nossek E, Torres J, Jain R, Riina HA, Radmanesh A, Nelson PK. Cerebral venous thrombosis associated with COVID-19. AJNR Am J Neuroradiol. 2020;41(8):1370-6. https://doi.org/10.3174/ajnr.A6644.

5. Dakay K, Cooper J, Bloomfield J, Overby P, Mayer SA, Nuoman R, Sahni R, Gulko E, Kaur G, Santarelli J, Gandhi CD, Al-Mufti F. Cerebral venous sinus thrombosis in COVID-19 infection: a case series and review of the literature. J Stroke Cerebrovasc Dis. 2021;30(1):105434. https://doi.org/10. 1016/j.jstrokecerebrovasdis.2020.105434.

\section{Publisher's Note}

Springer Nature remains neutral with regard to jurisdictional claims in published maps and institutional affiliations. 